\title{
Integrated Plant Nutrition System in Cotton - An Approach Towards Climate Change Mitigation
}

\author{
S. Praveena Katharine ${ }^{1 *}$, M. Suguna Devakumari ${ }^{2}$, S. Sumaiya Parveen ${ }^{3}$ \\ ${ }^{1}$ Assistant Professor, Department of Agriculture, Karunya Institute of Technology \\ and Sciences, Coimbatore, India \\ ${ }^{2}$ Assistant Professor, Department of Agriculture, Karunya Institute of Technology \\ and Sciences, Coimbatore, India \\ ${ }^{3}$ Assistant Professor, Department of Agriculture, Karunya Institute of Technology \\ and Sciences, Coimbatore, India \\ 1'praveenakate19@gmail.com, ${ }^{2}$ sugisathish@yahoo.com, \\ ${ }^{3}$ ssumaiyasaleem@gmail.com
}

\begin{abstract}
Agriculture is both affected by climate change but also contributes to it. As a sector, agriculture must therefore both adapt to changes and offers options for mitigation ie reducing greenhouse gas emissions and store carbon. The objective of the study is to explore the optimum level of plant nutrient for sustaining the desired crop productivity in hybrid cotton through optimization of benefit from all possible resources of plant nutrients in an integrated manner and to mitigate the green house gas emission through the adoption of Integrated Plant Nutrition System. The experiment was carried out in three locations with different soil fertility status with special emphasis to nitrogen levels in the soils. The fertilizer doses were fixed based on the soil test values and fertility grouping / indexing by International soil fertility evaluation and improvement programme. As part of organics, FYM was applied at two different levels, and the fertilizers were reduced accordingly. The results proved that application of organic manure@12.5 tha $a^{-1}$ along with the recommended doses of nutrients proved superior in seed cotton production as well reduced nitrous oxide emissions.
\end{abstract}

Keywords: Integrated Plant Nutrition System, Nitrous oxide emission, seed cotton yield

\section{Introduction}

India's economic security continues to be predicted upon the agricultural sector. The share of agriculture in GDP increased to 20.2 per cent in 2020-21 from 17.8 per cent in 2019-20. [1]. However, the natural resource base of agriculture, which provides for sustainable production is shrinking, degrading, and is adversely affecting the production capacity of the ecosystem. On the other hand, the demand for agriculture is

* S. Praveena Katharine, Assistant Professor, Department of Agriculture, Karunya Institute of Technology and Sciences, Coimbatore, India. E.mail: praveenakate19@gmail.com 
rising rapidly with increase in population, per capita income and the growing demand from industry sector. The Indian textile industry is tilted more towards environment friendly and biodegradable natural fibres of which cotton holds a high share of 60 per cent to the fibre basket. Natural fibres play a key role in the emerging "green" economy based on energy efficiency, reducing carbon emissions and recyclable waste materials.

Global surface air temperature is expected to increase the tune of $1.8-4.0{ }^{\circ} \mathrm{C}$ in the next few years resulting in severe yield reductions throughout the world [2]. One of the causative parameters of human-induced climate change is the emission of greenhouse gases (GHGs). About 10\% - 14\% of global GHG emissions is brought about by agriculture related activities [3][4], mostly from methane as a result of enteric fermentation, nitrous oxide, due to the application of synthetic fertilizers and carbon dioxide emitted during tillage operations [5]. As far as agriculture is concerned, the mineral fertilizers serve as a major source for the emission of greenhouse gases [6]. Research studies show that a reduction of methane emissions from agriculture up to $48 \%$ until 2030 as relative to 2010 [7] and a reduction of nitrous oxide emissions by $26 \%$ are highly essential to limit the global warming to $1.5^{\circ} \mathrm{C}$.

Cotton lint is an important textile fibre that comprises about 35 per cent of total world fibre use [8]. Cotton is grown in over 80 countries with China, India and the United States producing about two-thirds of total world output [9]. India has the largest area (12.18 million hectares) under cotton production. However, it stands second in production (25.5 million pound bales) next to China [9]. The potential productivity of the crop has not been fully exploited and needs important technological interventions for increasing the productivity of cotton.

Though, the fertilizer consumption in India has increased significantly in the last three decades, the lower per hectare NPK fertilizer consumption and imbalanced consumption ratio (6.7:3.1:1) in 2011-12 [10] against an optimum ratio of 4:2:1 leads to widespread negative nutrient balances in most Indian soils. This condition not only mirrors poor soil health, but also represents the severe on-going depletion of the soil's nutrient capital, degradation of the environment, and vulnerability of the crop production system in terms of its ability to sustain high yields [11]. Across cotton growing regions, nutrient balance is negative except for P [12]. The cotton plant is a heavy feeder and the nutrient management is complex due to the simultaneous production of vegetative and reproductive structures during the active growth phase.

Global nitrogen fertilizer consumption (produced by fossil energy) in 2005 was 90.86 million tonnes [13]. It takes approximately 90 million tonnes of fossil fuel (diesel equivalents) to produce this nitrogen fertilizer. This is about $1 \%$ of global fossil energy consumption. Modern industry uses $28 \mathrm{MJ} / \mathrm{kg}$ of ammonia under optimum conditions, but older technology may still use higher amounts of energy for fertilizer production [14]. The best technology available currently uses 0.76 litres of diesel equivalents, older technology between 1 and 1.5 litres to produce one $\mathrm{kg}$ of nitrogen fertilizer.

Nitrogen efficiency acts as a key factor for the reduction of greenhouse gases. Greenhouse gas emissions at farm level may be related either to the farm's nitrogen surplus or to the farm's nitrogen efficiency, as demonstrated by a scientific model of greenhouse gas emissions from European conventional and organic dairy farms [15]. Farm nitrogen surplus can therefore be a good proxy for greenhouse gas emissions per unit of land. Since organic crop systems are limited by the availability of nitrogen, they aim to balance their nitrogen inputs and outputs and their nitrogen efficiency. Their greenhouse gas emissions are thus lower than those of conventional farming systems.

Integrated Plant Nutrition System is a holistic approach to plant nutrition by obtaining the nutrients from both inorganic and organic sources to maintain and sustain soil fertility and enhance crop productivity in a framework of an ecologically compatible, 
socially acceptable and economically viable situation. Organic manures sustain soil fertility at a low level of production. Chemical fertilizers have concentrated forms of nutrients. Application results in leaching, fixation and build-up of certain nutrients at the expense of others, resulting in nutrient imbalances. Fertilizer use efficiency (FUE) is low in all chemical fertilizers and organic manure when used singularly. Combined use of organic manures and chemical fertilizers increases Fertilizer Use Efficiency.

To sustain crop yields, the rate of removal has to be balanced by added amounts. Use of chemical fertilizers is necessary for supplying the nutrient requirement but without recycling of crop residues, yields will suffer. If only organic manure is used land will benefit but yield will be lower. Availability of nutrients from organic manure is slow but long lasting. Use of organic manure improves the physical, chemical and biological conditions of the soil.

On account of the above facts, the present investigation was contemplated on hybrid cotton RCH530 on Periyanaickenpalayam soil series adopting Integrated Plant Nutrition System approach.

\section{Materials and methods}

The trial was laid out in Randomized Block Design with three replications, comprising of nine treatments based on the soil test values and fertilizer recommendation based on fertility grouping / indexing by International soil fertility evaluation and improvement programme [16] wherein the soils were grouped into low-medium-high categories. Arbitrarily, the recommended dose of fertilizer was increased by $25 \%$ in low status and reduced by $25 \%$ in high status. The sources of nutrients used for fertigation were urea, single super phosphate and muriate of potash. Under IPNS treatments, FYM with 32 per cent moisture and $0.64,0.31 \& 0.61$ percent of $\mathrm{N}, \mathrm{P}$ and $\mathrm{K}$ respectively was applied @ $6.25 \mathrm{t} \mathrm{ha}^{-1}$ and $12.5 \mathrm{tha}^{-1}$. Correspondingly, the nutrient doses were reduced by 20,10 and $17 \mathrm{~kg}$ of $\mathrm{N}, \mathrm{P}_{2} \mathrm{O}_{5}$ and $\mathrm{K}_{2} \mathrm{O}$ respectively when FYM was applied @ $6.25 \mathrm{tha}^{-1}$ and by 40, 20 and $34 \mathrm{~kg}$ of $\mathrm{N}, \mathrm{P}_{2} \mathrm{O}_{5}$ and $\mathrm{K}_{2} \mathrm{O}$ respectively when FYM was applied @ 12.5 $\mathrm{t} \mathrm{ha}^{-1}$ [17]. The soil available nutrient content and the doses of nutrients (fertilizers and organic manures) applied are provided in the Table 1.

All the agronomic practices were carried out periodically and the crop was grown to maturity. At harvest the seed cotton yield was recorded plot wise. The seed cotton, plant and post- harvest soils samples were collected from each plot and were processed for further analysis such as nutrient uptake pertaining to nitrogen, phosphorus and potassium. A fixed factor of $1.6 \%$ of the applied $\mathrm{N}$ is used to calculate $\mathrm{N} 2 \mathrm{O}$ emissions, from soils after application of fertilizer (in million tons $\mathrm{CO} 2$ equivalent) [18].

\section{Results and discussion}

In the first situation where the soil nutrient status is low for nitrogen, medium for phosphorus and high for potassium $\left(213: 16: 550 \mathrm{~kg} \mathrm{ha}^{-1}\right)$, the fertilizer doses applied were $150: 75: 75 \mathrm{~kg}$ of $\mathrm{N}: \mathrm{P}_{2} \mathrm{O}_{5}: \mathrm{K}_{2} \mathrm{O}$. Due to the addition of Farm Yard Manure @ 6.25 and $12.5 \mathrm{t} \mathrm{ha}^{-1}$, the fertiliser doses were reduced by $20: 10: 17 \mathrm{~kg} \mathrm{ha}^{-1}$ for $\mathrm{N}: \mathrm{P}_{2} \mathrm{O}_{5}: \mathrm{K}_{2} \mathrm{O}$ respectively. In a similar manner, the fertilizers were applied in the other two locations with different soil test values.

In all the locations, the seed cotton yield obtained was the highest in the treatment with FYM @12.5 t ha ${ }^{-1}$. This was closely followed by the treatments where FYM were applied at the rate of $6.25 \mathrm{tha}^{-1}$. 
Table 1. Pre-sowing soil available nutrient content, doses of nutrients applied, seed cotton yield and nitrous oxide emission (million tons $\mathrm{CO}_{2}$ equivalent).

\begin{tabular}{|c|c|c|c|c|c|c|c|c|}
\hline \multirow{2}{*}{$\begin{array}{c}\text { Soil } \\
\text { available } \\
\text { nutrient }(\mathrm{kg} \\
\left.\mathrm{ha}^{-1}\right)\end{array}$} & \multicolumn{2}{|c|}{ Nutrients applied } & \multirow{2}{*}{$\begin{array}{c}\text { Fertilizers } \\
\text { applied } \\
\begin{array}{c}\text { Urea:SSP:M } \\
\text { oP }\end{array}\end{array}$} & \multirow{2}{*}{$\begin{array}{l}\text { Seed } \\
\text { cotton } \\
\text { yield } \\
\left(\mathrm{kg} \mathrm{ha}^{-}\right. \\
\left.{ }_{1}\right)\end{array}$} & \multirow{2}{*}{$\begin{array}{c}\mathrm{N}_{2} \mathrm{O} \\
\text { emission } \\
\text { (million } \\
\text { tons } \mathrm{CO}_{2} \\
\text { equivt.) }\end{array}$} & \multicolumn{3}{|c|}{$\begin{array}{c}\text { Nutrient uptake (kg } \\
\left.\mathrm{ha}^{-1}\right)\end{array}$} \\
\hline & $\begin{array}{l}\mathrm{N}: \mathrm{P}_{2} \mathrm{O}_{5}: \\
\mathrm{K}_{2} \mathrm{O}\end{array}$ & $\begin{array}{l}\text { FYM } \\
\left(\text { tha }^{-1}\right)\end{array}$ & & & & $\mathrm{N}$ & $\mathrm{P}$ & K \\
\hline \multirow{3}{*}{$\begin{array}{l}\text { 213:16:550 } \\
\text { (site-1) }\end{array}$} & $150: 75: 75$ & 0 & $326: 469: 125$ & 3264 & 240 & 133.1 & 31.3 & 125.1 \\
\hline & & 6.5 & $306: 459: 108$ & 3332 & 208 & 144.3 & 33.2 & 129.2 \\
\hline & & 12.5 & 286:449:91 & 3373 & 176 & 151.8 & 41.7 & 137.6 \\
\hline \multirow{3}{*}{$\begin{array}{l}\text { 291:31:590 } \\
\text { (site-2) }\end{array}$} & $120: 60: 60$ & 0 & $260: 3$ & 3028 & 192 & 133.2 & 29.4 & 121.9 \\
\hline & & 6.5 & $240: 3$ & 3166 & 160 & 134.1 & 31.6 & 126.6 \\
\hline & & 12.5 & $220: 355: 66$ & 3405 & 128 & 152.8 & 47.6 & 140.1 \\
\hline \multirow{3}{*}{$\begin{array}{l}467: 32: 584 \\
\text { (site-3) }\end{array}$} & $90: 45: 45$ & 0 & $195: 281: 75$ & 3247 & 144 & 149.7 & 34.0 & 129.8 \\
\hline & & 6.5 & 175:271:58 & 3379 & 112 & 151.4 & 37.1 & 136.8 \\
\hline & & 12.5 & $155: 261: 50^{*}$ & 3401 & 96 & 152.6 & 46.5 & 139.6 \\
\hline
\end{tabular}

*Maintenance dose (50 per cent of the blanket dose for hybrids).

Though there was marked response to the application of NPK fertilizers, the magnitude of response was higher under IPNS as compared to NPK alone [19] [20] recorded a significant response to the application of NPK fertilizers along with FYM for cotton. The role of FYM is multidimensional ranging from building up of organic matter, maintaining favourable soil physical properties and balanced supply of nutrients. Further, FYM acts directly by increasing the crop yield either by accelerating the respiratory process through cell permeability or by hormone growth action. In the present investigation also, these factors might have contributed for the yield enhancement in cotton when NPK fertilisers are coupled with FYM.

The results pertaining to the beneficial aspects of reduction in nitrous oxide emissions due to the adoption of IPNS is clearly recorded in the present investigation. The nitrous oxide emission is the highest (240 million tons $\mathrm{CO}_{2}$ equivalent) in the case where the application of the fertilizer was the maximum. As the fertilizer nitrogen application reduces, the nitrous oxide emission also reduces. Nitrogen efficiency as a key factor for the reduction of greenhouse gases Greenhouse gas emissions at farm level may be related either to the farm's nitrogen surplus or to the farm's nitrogen efficiency, as demonstrated by a scientific model of greenhouse gas emissions from European conventional and organic dairy farms [15]. Farm nitrogen surplus can therefore be a good proxy for greenhouse gas emissions per unit of land. Since organic crop systems are limited by the availability of nitrogen, they aim to balance their nitrogen inputs and outputs and their nitrogen efficiency. Their greenhouse gas emissions are thus lower than those of conventional farming systems.

IPNS encompasses enhancement of crop and soil productivity through a balanced use of mineral fertilizers combined with organic and biological sources of plant nutrients to ensure sustainability of the production systems, improves the capital stock of plant nutrients in the soil and the efficiency of plant nutrients use, limiting the losses of $\mathrm{N}$ and $\mathrm{P}$ to the environment and thus promoting environmental security. Balanced fertilisation must be based on the concept of IPNS for a cropping system as this is the only viable strategy advocating accelerated and enhanced use of fertilisers with matching adoptions of organic manures and biofertilisers so that productivity is maintained for a sustainable agriculture. The balance has to be made in the soil-crop system over time and has to take care of all other factors of production and make allowances for residual effects of past fertiliser applications, biological $\mathrm{N}$ fixation, etc., and to ensure that there is no toxicity or 
deficiency of any element. The above concept of balanced fertilization is almost synonymous with that of IPNS [21].

In Integrated Plant Nutrition System, the reduction of mineral nitrogen considerably reduce the concentration of easily available mineral nitrogen in soils and thus $\mathrm{N}_{2} \mathrm{O}$ emissions. Addition of organic matter, increases the aeration in the soil and have significantly lower mobile nitrogen concentrations. Both factors reduce emissions of nitrous oxides. In a long-term study in southern Germany, Flessa et al. (2002) also found reduced nitrous oxide emission rates in the organic farm, although yield-related emissions were not reduced [22].

Soils managed with IPNS, are better adapted to weather extremes. Farming practices such as organic agriculture that preserve soil fertility and maintain or even increase organic matter in soils are in a good position to maintain productivity in the event of drought, irregular rainfall events with floods, and rising temperatures. They retain significantly more rain water due to the 'sponge properties' of organic matter. These 'sponge properties' were described for heavy loamy soils in a temperate climate in Switzerland where soil structure stability was $20-40 \%$ higher in organically managed soils than in conventional soils [23].

Thus the efficient use of applied nutrients was exhibited spectacularly under IPNS over NPK alone irrespective of the initial nutrient status of the soil. The saving of inorganic fertilisers for cotton with the application of FYM improves the economy of the farmers.

\section{Reference}

[1] National Statistical Office (NSO), M/o $\quad$ Statistics $\quad$ \& $\quad$ PI. (2021). https://www.pib.gov.in/PressReleasePage.

[2] Anjali Anand and Sangeeta Khetarpal, "Impact of Climate Change on Agricultural Productivity", Edited E.Bahadur, Plant Biology and Biotechnology., vol.1, (2015), pp.729-755.

[3] N.T. Francesco, S. Mirella, R. Simone, F. Alessandro, F. Nuala and S. Pete, "The FAOSTAT database of greenhouse gas emissions from agriculture”. Environ. Res. Lett., (2013), 8.

[4] P. Smith, D. Martino, Z. Cai, D. Gwary, H. Janzen, P. Kumar, B. McCarl, S. Ogle, F. O'Mara and C. Rice, "Greenhouse gas mitigation in agriculture", Philos. Trans. R. Soc. Lond. B Biol. Sci., vol. 363, No.1492, (2008), pp. 789-813.

[5] C.B. Field, V. Barros, T.F. Stocker, D. Qin, D.J. Dokken, K.L. Ebi, M.D. Mastrandrea, K.J. March, G.K. Plattner and S.K. Allen, Editors, "Managing the Risks of Extreme Events and Disasters to Advance Climate Change Adaptation", A special report of working groups I and II of the IPCC, Cambridge University Press, Cambridge, UK and New York, NY, USA, (2012), pp. 582.

[6] H. Singh, B.K. Northup, G.S. Baath, P.P. Gowda and V.G. Kakani, "Greenhouse mitigation strategies for agronomic and grazing lands of the US Southern Great Plains”, In: Mitig. Adapt. Strateg. Glob. Chang. Springer edition, vol.5, (2019).

[7] https://www.unwater.org/publications/highlights-sdg-6-synthesis-report-2018-on-water-andsanitation-2/

[8] United States Department of Agriculture, Economic Research Service. (2011), <http://www.ers.usda.gov/Briefing/Cotton/>

[9] United States Department of Agriculture, -Foreign Agriculture Service. (2013), ttp://www.cotton.org/econ/cropinfo/cropdata/rankings.cfm.

[10] Satish Chander, "Adoption of fertilizer best management practice", Indian Journal of Fertilizers., vol.9, No.4, (2013), pp.10-11.

[11] H.L.S.Tandon, "Soil Nutrient Balance Sheets in India: Importance, Status, Issues, and Concerns", Better Crops - India., (2007), pp. 15-19.

[12] M.V. Venugopalan, D. Blaise, M.S. Yadav and Rachana Deshmukh, "Fertilizer response and nutrient management strategies for cotton", Indian Journal of Fertilizers., vol. 7, No. 4, (2011), pp. 82-94.

[13] Karthik Nagendra, "Organic farming has positive impact on climate change", IFA, (2007), http://www.fertilizer.org/

[14] T. Gerlagh and A.W.N. Van Dril, "The fertiliser industry and its energy use - Prospects for the Dutch energy intensive industry", ECN Policy Studies Edition, Energy Research Centre of the Netherlands (ECN), Petten (NL). (1999), pp 58. 
[15] J.E. Olesen, K. Schelde, A. Weiske, M.R. Weisbjerg, W.A.H. Asman and J. Djurhuus, "Modelling greenhouse gas emissions from European conventional and organic dairy farms", Agriculture, Ecosystems and Environment, vol. 112, (2006), pp.207-22.

[16] D.L. Waugh and J.W. Fitts, "Soil test interpretation studies: Laboratory and potted plant", Tech. Bull. North. Carolina State Agric. Exp. Stn., (ISTP Series) No. 3. (1966).

[17] S. Praveena Katharine, R. Santhi, S. Maragatham, R. Natesan, V. Ravikumar and Pradip Dey, "Soil Test Based Fertilizer Prescriptions through Inductive Cum Targeted Yield Model for Transgenic Cotton On Inceptisol”, IOSR Journal of Agriculture and Veterinary Science (IOSR-JAVS), vol.6, No.5, (2013), pp. 36-44.

[18] https://www.fibl.org/fileadmin/documents/shop/1500-climate-change.pdf

[19] K. Mahavishnan, Mangal Prasad and K. Bhanu Rekha, "Integrated nutrient management in cotton sunflower cropping system in the sandy loam soils of north India", J. of Tropic. Agric., vol. 43, No. 1-2, (2005), pp. 29-32.

[20] Anonymous, "Project Coordinator's Report, All India Coordinated Cotton Improvement Project" Annual Report, (2011-12).

[21] N.N. Goswami, "Some thoughts on the concept, relevance and feasibility of IPNS under Indian conditions", Integrated Plant Nutrient Supply System for Sustainable Productivity, Bull. Indian Instt Soil Sci., vol. 2, (1998), pp. 3-9.

[22] H. Flessa, R. Ruser, P. Dorsch, T. Kamp, M.A. Jimenez, J.C. Munch and F. Beese, "Integrated evaluation of greenhouse gas emissions $\left(\mathrm{CO}_{2}, \mathrm{CH}_{4}, \mathrm{~N}_{2} \mathrm{O}\right)$ from two farming systems in Southern Germany", Agriculture, Ecosystems and Environment, vol. 91, (2002), pp. 175-189.

[23] P. Mader, A. Fliebach, D. Dubois, L. Gunst, P. Fried, U. Niggli, "Soil fertility and biodiversity in organic farming", Science, vol. 296, (2002), pp. 1694-1697. 